\title{
MEDIA LINGKUNGAN SEKOLAH MENINGKATKAN KETERAMPILAN MENULIS DESKRIPSI KELAS IV SD
}

\author{
Ida Putriani, Sri Murdiyah, Rochani \\ Universitas Negeri Malang \\ Email : ieda_putri0415@yahoo.com
}

\begin{abstract}
Abstrak: Penelitian bertujuan untuk mengetahui penerapan dan peningkatan keterampilan menulis deskripsi melalui media lingkungan sekolah. Penelitian yang dilakukan adalah penelitian tindakan kelas dengan dua siklus yang terdiri dari tahap perencanaan, pelaksanaan, observasi, dan refleksi. Hasil penelitian di SDN Bacem 03 Sutojayan Blitar menunjukkan peningkatan aktivitas guru dan siswa dengan rata-rata persentase aktivitas guru 97\% dan aktivitas siswa 94\%. Hasil menulis siswa meningkat mencapai ketuntasan klasikal 100\%.
\end{abstract}

Kata kunci : peningkatan, keterampilan menulis, media lingkungan sekolah

Menulis merupakan salah satu dari empat keterampilan berbahasa yang harus dimiliki siswa. Menulis adalah suatu proses menuangkan pikiran, gagasan, pendapat tentang sesuatu, tanggapan terhadap suatu pernyataan keinginan, atau pengungkapan perasaan dengan menggunakan bahasa tulis (Rofiuddin dan Zuhdi, 1999: 263). Kegiatan menulis di SD diberikan kepada anak sejak di kelas rendah hingga kelas tinggi. Pembelajaran menulis di SD dibedakan menjadi dua yakni pembelajaran menulis permulaan dan pembelajaran menulis lanjut. Menulis lanjutan diberikan dikelas tinggi, karena siswa di kelas tinggi telah menguasai dasar menulis yang akan digunakan sebagai dasar mengembangkan kemampuan bahasa tulis siswa. Salah satu kemampuan yang harus dikembangkan siswa dalam tahap menulis lanjut adalah penguasaan pengembangan menulis berbagai bentuk ragam tulisan baik narasi, deskripsi, argumentasi atau eksposisi. Salah satu ragam tulisan yang diberikan pada siswa kelas IV adalah menulis deskripsi.

Berdasarkan hasil observasi pada tanggal 22 Januari 2015 di SDN Bacem 03 Sutojayan Blitar adalah rendahnya keterampilan siswa dalam menulis deskripsi yang disebabkan oleh (1) siswa kesulitan dan tidak percaya diri dalam mengungkapkan ide atau gagasannya dalam bentuk tulisan, (2) siswa kurang teliti dalam menulis paragraf (3) rendahnya kemampuan siswa dalam memadukan hubungan antar kalimat (4) rendahnya minat dan motivasi siswa dalam pembelajaran menulis deskripsi. Serta guru tidak menggunakan media pada saat pembelajaran.

Salah satu media yang dapat digunakan dalam pembelajaran menulis adalah dengan memanfaatkan lingkungan sekolah. Dengan menggunakan media lingkungan, yakni lingkungan sekolah siswa belajar tidak terbatas ruang kelas, serta kebenaran yang didapatkan siswa akan lebih akurat karena siswa mendapatkan sendiri dan mengalami secara langsung segala informasi yang diperolehnya. Arsyad (2011:10) mengungkapkan bahwa pengalaman langsung akan memberikan kesan paling utuh dan paling bermakna mengenai informasi dan gagasan yang terkandung dalam pengalaman itu. Tulisan ini mendeskripsikan tentang media belajar lingkungan sekolah yang dapat meningkatkan keterampilan menulis deskripsi siswa kelas IV SD. 


\section{METODE}

Pendekatan yang digunakan dalam penelitian adalah pendekatan kualitatif. Dengan jenis penelitian penelitian tindakan (Action Research) yang dilakukan dengan tujuan memperbaiki mutu praktik pembelajaran di kelasnya(Arikunto, 2012:58). Model yang digubakan dalam penelitian ini menggunakan model spiral dari Kemmis dan Taggart (dalam Arikunto 2012:50). Pada model ini terdapat empat tahapan utama kegiatan, yaitu perencanaan, tindakan, pengamatan, dan refleksi. Penelitian ini dilakukan dalam dua siklus dengan melaksanakan tahap pratindakan terlebih dahulu.

Dalam penelitian ini, peneliti bertindak sebagai perencana, pelaksana, pengumpul data, penganalisis data, dan pelapor data. Peneliti juga dibantu guru kelas yang bertugas sebagai observer. Penelitian ini dilaksanakan di kelas IV SDN Bacem 03 Kecamatan Sutojayan Kabupaten Blitar pada semester genap tahun ajaran 2014/2015. Subjek penelitian berjumlah 23 siswa, terdiri dari 7 siswa lakilaki dan 16 siswa perempuan.

Data yang digunakan dalam penelitian adalah data proses dan data hasil. Data proses diperoleh dari hasil pengamatan aktivitas siswa pada saat pembelajaran menulis deskripsi, dan kemampuan guru saat proses pembelajaran berlangsung, adapun data hasil diperoleh dari hasil menuli deskripsi siswa yang dilaksanakan pada tahap pra tindakan dan pada tiap akhir siklus. Sumber data dalam penelitiaan ini diperoleh dari guru dan siswa kelas IV SDN Baecem 03 Sutojayan Kabupaten Blitar.

Teknik pengumpulan data yang digunakan dalam penilitian ini meliputi observasi, tes, dokumentasi, dan catatan lapangan. Instrumen yang digunakan dalam penelitian ini meliputi lembar observasi aktivitas guru, lembar observasi aktivitas siswa, lembar penilaian hasil menulis deskripsi siswa, dan lembar catatan lapangan. Teknik analisa data yang dilakukan meliputi tiga kegiatan yaitu reduksi data, penyajian data, dan penarikan kesimpulan.

\section{HASIL}

\section{Pratindakan}

Pada tahap pratindakan ini peneliti melakukan observasi pada siswa kelas IV SDN Bacem 03 Kecamatan Sutojayan Kabupaten Blitar. Kegiatan observasi ini dilakukan hari Senin tanggal 26 Januari 2015. Peneliti melakukan observasi pada pembelajaran bahasa Indonesia dengan materi menulis deskripsi. Siswa diminta untuk menulis deskripsi dari pengalaman liburannya. Rata-rata nilai menulis siswa kelas IV adalah 61. Apabila dipersentasekan, maka siswa yang sudah tuntas sebesar 35\% . Berdasarkan dari observasi pada tahap pratindakan maka dilakukan refleksi sebagai berikut, (1) guru hanya menggunakan metode ceramah, tanya jawab, dan penugasan, (2) guru tidak menggunakan media pembelajaran, guru hanya menyuruh siswa untuk membuat tulisan deskripsi, (3) siswa terlihat kurang semangat dalam mengikuti pembelajaran karena mereka hanya duduk diam dan mendengarkan, (4) perlu digunakan metode yang tepat agar siswa ikut aktif dalam kegiatan pembelajaran, (5) perlu digunakan media untuk membantu siswa dalam memahami materi pembelajaran.

\section{Pelaksanaan \\ Siklus I}

Kegiatan pembelajran pada Siklus I dilaksanakan dua kali pertemuan yakni 29 Januari 2015 dan 2 Februari 2015. Pada kegiatan ini guru melakukan beberapa perencanaan antara lain menyusun RPP, menyiapkan materi yang sesuai dengan tujuan pembelajaran, LKK dan LKS mempersiapkan media dan sumber belajar, penyusunan lembar observasi aktivitas siswa dan aktivitas guru selama kegiatan pembelajaran serta lembar penilaian hasil belajar menulis siswa.

Materi pokok pada pertemuan pertama membahas tentang tulisan deskripsi dan langkah-langkah menyusun tulisan deskripsi dengan menggunakan media lingkungan sekolah. Guru bertanya jawab dan memberikan contoh menuliskan data-data penting dari ob- 
jek papan tulis yang ada di kelas untuk menyusun tulisan deskripsi. Pada kegiatan penyampaian materi ini ditemui siswa yang kurang memperhatikan penjelasan guru. Dalam proses pembuatan kerangka karangan ini ditemui beberapa kendala dimana hampir semua kelompok belum paham tentang menyusun kerangka karangan, sehingga guru memberikan bimbingan pada kelompok.

Pada pertemuan 2 materi yang diajarkan pada pembelajaran ini masih tentang menulis deskripsi dengan menggunakan media lingkungan sekolah. Siswa mengamati lingkungan kantin untuk dideskripsikan. Dalam kegiatan ini siswa terlihat bersemangat, namun karena untuk pertama keluar kelas siswa menjadi sulit fokus pada apa yang ditugaskan. Siswa kembali ke kelas dan menyusun kerangka serta mengembangkan kerangka menjadi tulisan deskripsi. Beberapa siswa sudah mulai terbiasa menyusun kerangka. Serta menyampaikannya di muka kelas.

\section{Siklus II}

Pada siklus II ini peneliti melakukan kegiatan-kegiatan perencanaan dengan mempertimbangkan hasil refleksi dari siklus I. Kegiatan kegiatan tersebut antara lain menyusun RPP dengan menggunakan media lingkungan sekolah, menyiapkan materi tentang menulis deskripsi yang lengkap dan sesuai, (LKS), mempersiapkan media dan sumber belajar, penyusunan lembar observasi aktivitas siswa dan aktivitas guru selama kegiatan pembelajaran serta lembar penilaian hasil belajar menulis siswa. Dan juga menyiapkan reward berupa bintang bagi siswa yang aktif dalam pembelajaran.

Pada pertemuan pertama siklus II ini materi pembejaran yang diajarkan adalah menulis deskripsi dengan menggunakan media lingkungan sekolah yakni lapangan sekolah. Siswa mengamati lingkungan sekolah selanjutnya menetukan objek, menulis data-data penting, membuat kerangka, dan mengembangkan kerangka karangan. Siswa sudah mulai terbiasa melakukan pengamatan dan mem- buat tulisan deskripsi, tetapi masih ada siswa yang belum maksimal.

Pada pertemuan kedua siklus II, materi pembejaran yang diajarkan adalah menulis deskripsi dengan menggunakan media lingkungan sekolah yakni perpustakaan. Siswa semangat dan antusias dalam kegiatan. Nilai proses dan hasil siswa juga menunjukkan adanya peningkatan hingga mencapai ketuntasan.

\section{Refleksi}

Berdasarkan paparan data dan hasil penelitian pada siklus I dan siklus II, pembelajaran menulis deskripsi dengan menggunakan media lingkungan sekolah berjalan dengan lancar sesuai langkah-langkah kegiatan yang telah disiapkan. Dari siklus I diperoleh temuan diantaranya (1) presentase keberhasilan guru dalam mengajar sebesar $85 \%$ yang termasuk dalam kriteria B (Baik), (2) guru telah melaksanakan pembelajaran dengan baik sesuai dengan RPP yang telah disusun, (3) guru menggunakan media yang dapat menarik keantusiasan siswa dalam menulis deskripsi, dan (4) masih ada siswa yang belum aktif dan kurang memperhatikan penjelasan guru, kurang berkerjasama dengan kelompok, serta kurang percaya diri.

Pada siklus II, diperoleh temuan diantaranya (1) persentase keberhasilan guru dalam pembelajaran sebesar 97\%, (2) guru telah melatih siswa yang belum aktif dan kurang percaya diri dalam pembelajaran sebelumnya menjadi ikut aktif ,semangat, serta percaya diri dalam mengikuti pembelajaran, (3) semua siswa tampak bersemangat dan senang mengikuti pembelajaran, dan (4) siswa sudah terbiasa dalam melakukan pengamatan, pengumpulan data, membuat kerangka, dan mengembangkan kerangka karangan sehingga guru tidak perlu membimbing masing-masing siswa.

Selain hal-hal tersebut, juga terjadi peningkatan pada nilai proses dan nilai hasil menulis siswa dengan menggunakan media lingkungan dari siklus I ke siklus II. 
Peningkatan tersebut seperti yang ditunjukkan pada tabel 1.

Dalam tabel ini dapat dilihat bahwa terjadi peningkatan aktivitas siswa dalam menulis deskripsi menggunakan media lingkungan sekolah yakni pada siklus I 78,5\% dan pada siklus II 94,5\%. Sementara itu nilai hasil menulis deskripsi siswa juga mengalami peningkatan dari siklus I ke siklus II. Peningkatan tersebut dipaparkan pada tabel 2.

\section{PEMBAHASAN}

Berdasarkan paparan hasil penelitian, diketahui bahwa pembelajaran menulis deskripsi menggunakan media lingkungan sekolah dilaksanakan melalui dua siklus, yaitu siklus I dan siklus II. Pembelajaran yang dilaku- kan pada siklus I sudah berjalan dengan baik. Dalam pembelajaran guru telah menggunakan RPP dan menggunakan media lingkungan sekolah sebagai media dalam menulis deskripsi. Metode pembelajaran yang dilakukan guru adalah metode pengamatan, ceramah, tanya jawab, dan pemberian tugas. Siswa membuat tulisan deskripsi dengan memanfaatkan media lingkungan karena dalam menulis deskripsi dibutuhkan pengamatan mendalam dari objek yang akan dideskripsikan guna menunjang kelengkapan tulisan. Hal ini sesuai dengan yang dikemukakan oleh Akhadiah,dkk (1993: 97) bahwa perlu dilakukan pengamatan yang mendalam sebelum memulai menulis deskripsi.

Aktivitas guru dalam siklus I dilaksanakan dengan baik mulai dari menyusun RPP,

Tabel 1 Perbandingan Hasil Aktivitas Siswa secara klasikal dalam Kegiatan Menulis Deskripsi Menggunakan Media Lingkungan Sekolah siklus I dan siklus II

\begin{tabular}{ccc}
\hline Siklus & Nilai rata-rata proses & Kriteria \\
\hline Siklus I & $78,5 \%$ & B (Baik) \\
Siklus II & $94,5 \%$ & A (Sangat Baik) \\
\hline
\end{tabular}

Tabel 2 Perbandingan Hasil Menulis Deskripsi Siswa Dengan Menggunakan Media Lingkungan Sekolah siklus I dan siklus II

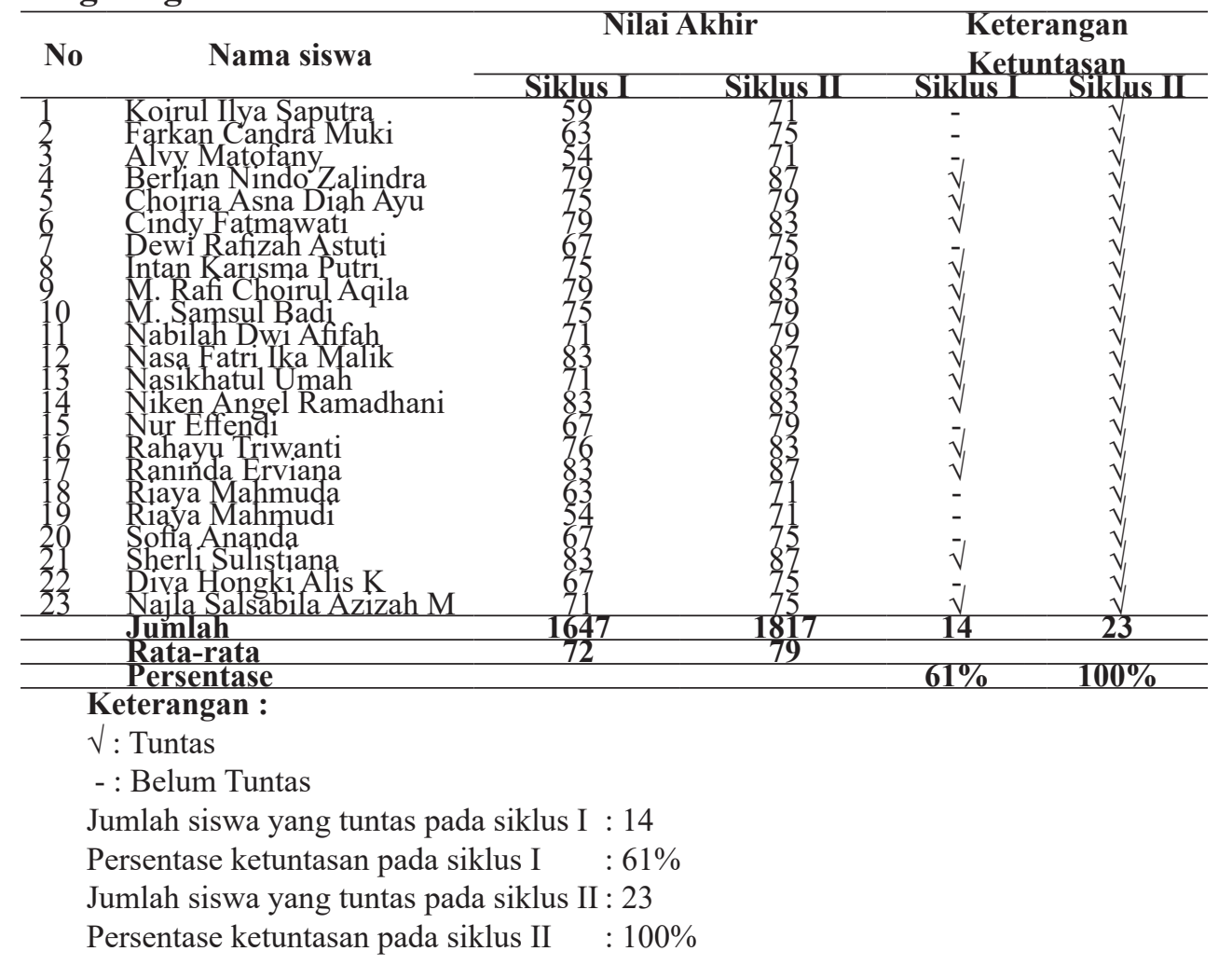


menyiapkan media, membimbing siswa, dan melaksanakan evaluasi dan refleksi. Kegiatan yang dilakukan selama pembelajaran telah sesuai dengan langkah-langkah penggunaan lingkungan sebagai media pembelajaran. Langkah-langkah tersebut seperti yang dikemukakan oleh (Sudjana \& Rivai, 2010: 215) yaitu diantaranya langkah persiapan, pelaksanaan, dan tindak lanjut.

Siswa dalam kegiatan menulis deskripsi menggunakan media lingkungan nampak antusias dan aktif selama pembelajaran. Namun, pada pembelajaran siklus I terdapat beberapa permasalahan, sehingga hasil menulis siswa belum tercapai secara maksimal. Permasalahan-permasalahan yang terjadi diantaranya guru belum mengelola kelas dengan baik yang ditunjukkan masih ada siswa yang kurang memperhatikan guru saat menjelaskan materi, pengelolaan waktu yang belum maksimal, hal ini disebabkan saat pengamatan diluar kelas siswa masih belum fokus dalam tugasnya. Namun, jika dilihat dari nilai akhir, ada peningkatan pada nilai siswa meskipun belum tuntas dibandingkan dengan pratindakan

Pada kegiatan pembelajaran yang dilaksanakan di siklus II pelaksanaan pembelajaran sudah sangat baik. Guru telah berhasil mengelola kelas dengan baik. Guru juga membimbing siswa dalam menyusun kerangka dan mengembangkan kerangka karangan menjadi tulisan deskripsi dengan memperhatikan ejaan dan tanda baca. Selain itu guru juga menggunakan reward sebagai motivasi siswa dalam menulis sehingga siswa menjadi lebih semangat, percaya diri, dan aktif selama pembelajaran.

Pada siklus II ini siswa juga lebih aktif dalam pembelajaran dibandingkan siklus I, siswa melakukan kegiatan menulis deskripsi dengan menggunakan media lingkungan dengan baik mulai dari menentukan objek, melakukan pengamatan, mengumpulkan data, membuat kerangka, dan mengembangkan kerangka menjadi tulisan deskripsi serta dengan percaya diri membacakan hasil tulisan- nya dimuka kelas. Kegiatan yang dilakukan siswa ini telah sesuai dengan langkah-langkah menulis deskripsi yang dikemukakan oleh (Akhadiah,dkk. 1993: 97) yakni (1) menentukan objek yang akan dideskripsikan, (2) siswa diajak mengamati objek yang telah ditentukan dalam waktu tertentu, (3) siswa mendeskripsikan hasil pengamatannya tersebut, (4) beberapa karangan siswa dibacakan didepan kelas dan guru membetulkan kesalahan siswa, (5) untuk mengetahui kemampuan siswa dalam menerapkan ejaan,struktur kalimat,pilihan kata, koherensi antar kalimat beberapa paragraf ditulis dipapan tulis.

Berdasarkan penelitian ini juuga diketahi adanya peningkatan keterampilan menulis deskripsi siswa kelas IV SDN Bacem 03 dari mulai tahap pratindakan, siklus I, dan siklus II dengan menggunakan media lingkungan sekolah.

Pada siklus I guru menggunakan media lingkungan sekolah sebagai media dalam pembelajaran menulis deskripsi, dengan persentase rata-rata aktivitas guru pada siklus I sebesar $85 \%$. Pada siklus II persentase ratarata aktivitas guru 97\%. Persentase tersebut menunjukkan terjadinya peningkatan aktivitas guru dalam menggunakan media. Peningkatan juga terjadi pada aktivitas siswa. Pada siklus I persentase rata-rata aktivitas siswa sebesar $79 \%$. Pada siklus II persentase rata-rata aktivitas siswa sebesar 94,5\%. Peningkatan ini membuktikan bahwa pembelajaran yang dilakukan guru dengan menggunakan media lingkungan sekolah dapat meningkatkan aktivitas siswa.

Selain aktivitas guru dan siswa juga diperoleh nilai menulis deskripsi. Pada pembelajaran menulis deskripsi yang telah dilakukan pada pratindakan diperoleh hasil yakni dari 23 siswa $8(35 \%)$ siswa tuntas dalam kegiatan menulis deskripsi yakni memperoleh nilai diatas KKM, sementara 15(65\%) siswa belum tuntas dan mendapat nilai dibawah KKM dengan rata-rata klasikal 61. Hasil pembelajaran menulis deskripsi dengan 
menggunakan media lingkungan sekolah pada siswa kelas IV SDN Bacem pada siklus I menunjukkan adanya keberhasilan dan juga meningkat dari hasil yang diperoleh dari hasil menulis pada pratindakan. Hal ini ditunjukkan dengan peningkatan persentase ketuntasan klasikal yang diperoleh dari tahap pratindakan sebesar 35\% menjadi sebesar $61 \%$ yakni sebanyak 14 siswa yang mencapai nilai KKM dengan nilai rata-rata menulis deskripsi 72 . Namun, ketuntasan klasikal yang diperoleh dari siklus I ini belum mencapai ketuntasan klasikal yang ditetapkan yaitu $75 \%$, sehingga masih perlu diadakan perbaikan pada siklus II.

Pada siklus II, pembelajaran yang dilakukan semakin baik. Hasil belajar siswa dalam menulis deskripsi juga semakin baik apabila dibandingkan dengan sikus I. hal ini berdasarkan kegiatan pembelajaran yang diperbaiki guru dari hasil refleksi siklus I yaitu mengenai cara menyusun kerangka dan mengembangkan kerangka menjadi karangan deskripsi yang memperhatikan ejaan dan tanda baca yang tepat. Sehingga siswa tidak lagi kesulitan dalam menulis deskripsi dan menghasilkan tulisan deskripsi yang lengkap. Dengan menggunakan media lingkungan sebagai media menulis deskripsi pada siklus II ini, hasil belajar menunjukkan terjadinya peningkatan dan ketuntasan klasikal kelas IV SDN Bacem 03 Blitar. Peningkatan hasil tersebut yakni sebanyak 23 siswa telah mencapai KKM atau dengan persentase $100 \%$ dan nilai rata-rata 79 . Persentase klasikal yang diperoleh pada siklus II meningkat dibandingakan dengan siklus I dengan peningkatan sebesar 39\% yakni dari siklus I sebesar $61 \%$ pada siklus II menjadi sebesar $100 \%$.

Kegiatan pembelajaran dengan menggunakan media lingkungan, terbukti berhasil meningkatkan aktivitas guru dan aktivitas siswa dalam pembelajaran menulis deskripsi. Adanya peningkatan tersebut membuktikan bahwa guru melaksanakan pembelajaran dengan baik serta siswa dapat menerima dan memahami pembelajaran yang diajarkan oleh guru. Peningkatan aktivitas siswa pada siklus I ke siklus II ini dikarenakan adanya penggunaan media dalam pembelajaran. Media tersebut adalah media lingkungan sekolah, seperti yang dikemukakan oleh Sudjana \& Rivai (2010:208) tentang keuntungan menggunakan media lingkungan dalam pembelajaran antara lain 1) kegiatan belajar lebih menarik dan tidak membosankan siswa duduk di kelas berjam-jam, sehingga motivasi belajar akan lebih tinggi, (2) hakikat belajar akan lebih bermakna karena siswa dihadapkan dengan situasi dan keadaan yang sebenarnya atau bersifat alami, (3) bahan-bahan yang dipelajari lebih kaya serta lebih faktual sehingga kebenarannya lebih akurat, (4) kegiatan belajar siswa lebih komperhensif dan lebih aktif sebab dapat dilakukan dengan berbagai cara seperti mengamati, bertanya atau wawancara, membuktikan atau mendemonstrasikan, menguji fakta, dan lain-lain, (5) sumber belajar menjadi lebih kaya sebab lingkungan yang dapat dipelajari bisa beraneka ragam seperti lingkungan sosial, lingkungan alam, lingkungan buatan, dan lain-lain, (6) siswa dapat memahami dan menghayati aspek-aspek kehidupan yang ada di lingkungan, sehingga membentuk pribadi yang tidak asing dengan kehidupan di sekitarnya, serta dapat memupuk cinta lingkungan.

Berdasarkan data yang diperoleh, penggunaan media lingkungan sekolah sebagai media dalam menulis deskripsi dapat meningkatkan aktivitas dan keterampilan siswa dalam menulis deskripsi. Dengan menggunakan media lingkungan sekolah sebagai media pembelajaran, siswa menjadi lebih peka terhadap lingkungannya sehingga memudahkan siswa dalam menentukkan objek dan data-data objek yang akan ditulisnya menjadi tulisan deskripsi. Seperti yang dikemukakan oleh Arsyad,Azhar (2011:10) bahwa pengalaman langsung akan memberikan kesan paling utuh dan paling bermakna mengenai informasi dan gagasan yang terkandung dalam pengalaman itu. Oleh karena itu belajar dari lingkungan 
langsung seperti lingkungan sekolah akan memberikan dampak pada siswa karena siswa mengalaminya sendiri secara alami, sehingga lebih nyata, lebih faktual dan kebenarannya dapat dipertanggungjawabkan.

\section{PENUTUP}

\section{Kesimpulan}

Berdasarkan penelitian yang dilakukan tentang pemanfaatan media lingkungan sebagai media dalam menulis deskripsi diperoleh kesimpulan. Dengan menggunakan media lingkungan sebagai media dalam pembelajaran menulis deskripsi dapat meningkatkan keterampilan menulis deskripsi siswa kelas IV SDN Bacem 03 Kabupaten Blitar dalam hal penggambaran objek, penggunaan ejaan, diksi dan keutuhan karangan. Hal ini dibuktikan dengan adanya peningkatan hasil menulis deskripsi siswa dengan rincian sebagai berikut; pada pratindakan ketuntasan klasikal hanya 8 siswa atau $35 \%$, pada siklus I ketuntasan klasikal meningkat menjadi 15 siswa atau $61 \%$, dan pada siklus II terjadi peningkatan ketuntasan klasikal yang signifikan yaitu 23 siswa atau sebesar $100 \%$.

\section{Saran}

Berdasarkan kesimpulan diatas dapat disampaikan beberapa saran sebagai berikut. Hendaknya guru memanfaatkan media lingkungan sekolah sebagai media dalam pembelajaran khususnya dalam kegiatan menulis deskripsi untuk meningkatkan keterampilan menulis deskripsi siswa. Diharapkan kepada semua pihak untuk dapat menerapkan pembelajaran dengan berbagai metode atau teknik yang menyenangkan serta menggunakan media pembelajran yang menyenangkan agar tercipta ruang kelas yang aktif dan efektif sehingga tujuan pembelajaran yang telah direncanakan tercapai

\section{DAFTAR RUJUKAN}

Akhaidah, Sabarti dkk. 1993. Bahasa Indonesia II. Jakarta: Departemen Pendidikan dan Kebudayaan Direktorat Jenderal Pendidikan Tinggi

Akhaidah, Sabarti dkk. 1993. Bahasa Indonesia III. Jakarta: Departemen Pendidikan dan Kebudayaan Direktorat Jenderal Pendidikan Tinggi

Arikunto, dkk. 2012. Penelitian Tindakan Kelas. Jakarta: PT. Bumi Angkasa

Arsyad, Azhar. (2011). Media Pembelajaran. Jakarta: PT Raja Grafindo Persada

Sudjana, Nana dan Ahmad Rivai.2010. Media Pengajaran.Bandung: Sinar Baru Algensindo

Zuhdi, Darmiyati dan Rofiudin, Ahmad. 1999. Pendidikan Sastra dan Bahasa Indonesia di Kelas Tinggi. Jakarta: Departemen Pendidikan dan Kebudayaan Direktorat Jenderal Pendidikan Tinggi 